https://doi.org/10.15407/ujpe66.5.429

V.P. KOSTYLYOV ${ }^{1}$ A.V. SACHENKO,${ }^{1}$ V.M. VLASIUK, ${ }^{1}$ I.O. SOKOLOVSKYI, ${ }^{1}$ S.D. KOBYLIANSKA, ${ }^{2}$ P.V. TORCHYNIUK, ${ }^{2}$ O.I. V'YUNOV ${ }^{2}$ A.G. BELOUS ${ }^{2}$

${ }^{1}$ V.E. Lashkaryov Institute of Semiconductor Physics, Nat. Acad. of Sci. of Ukraine (41, Prosp. Nauky, Kyiv 03680, Ukraine; e-mail: vkost@isp.kiev.ua)

${ }^{2}$ V.I. Vernadsky Institute of General and Inorganic Chemistry, Nat. Acad. of Sci. of Ukraine (32/34, Palladina Pr., Kyiv 03142, Ukraine)

\title{
SYNTHESIS AND INVESTIGATION OF THE PROPERTIES OF ORGANIC-INORGANIC PEROVSKITE FILMS WITH NON-CONTACT METHODS
}

\begin{abstract}
We present the results of studies of the photoelectric properties of perovskite $\mathrm{CH}_{3} \mathrm{NH}_{3} \mathrm{PbI}_{2.98} \mathrm{Cl}_{0.02}$ films deposited on a glass substrate using the spin-coating method. The unit cell parameters of perovskite are determined, by using X-ray diffractometry. It is shown that the film morphology represents a net of non-oriented needle-like structures with significant roughness and porosity. In order to investigate the properties of the films obtained, we used non-contact methods such as transmission and reflection measurements and the measurements of the spectral characteristics of the small-signal surface photovoltage. The non-contact method of spectral characteristics of the small-signal surface photovoltage and the transmission method reveal information about the external quantum yield in the films studied and about the diffusion length of minority carriers in the perovskite films. As a result of this analysis, it has been established that the films are naturally textured, and their bandgap is $1.59 \mathrm{eV}$. It is shown that, in order to correctly determine the absorption coefficient and the bandgap values, the Urbach effect should be accounted for. The diffusion length of minority carriers is longer than the film thickness, which is equal to $400 \mathrm{~nm}$. The films obtained are promising materials for solar cells and optoelectronic devices.
\end{abstract}

Ke ywords: surface photovoltage, perovskite film, diffusion length, transmission spectra, Urbach effect.

\section{Introduction}

An increase of the world energy consumption with hydrocarbons and atomic energy as primary sources has created a number of ecological, technological, social, and recently also economic problems. This has led to a growing of interest in the renewable energy sources. One of the most attractive and promising re-

(C) V.P. KOSTYLYOV, A.V. SACHENKO, V.M. VLASIUK, I.O. SOKOLOVSKYI, S.D. KOBYLIANSKA,

P.V. TORCHYNIUK, O.I. V'YUNOV,

A.G. BELOUS, 2021 newable sources of energy is photovoltaics, that is, a direct transformation of the solar radiation energy into electricity. Increasing the efficiency of the photovoltaic energy conversion and decreasing the production cost per unit of energy remains an important problem since quite a long time. The promising candidates that can solve the above-pointed problems are solar cells (SCs) based on the organic/inorganic lead halide perovskite $[1,2]$. These are direct-bandgap materials, implying high optical absorption coefficient value. SCs based on these materials belong to the second generation of thin-film SCs [3]. As com- 
pared to the traditional SCs based on monocrystalline silicon, their fabrication technology is simpler, because it does not require high temperatures, which reduces the price of these SCs. In addition, during the several years of their investigation, the efficiency of these cells has increased to $20.9 \%$ for the SC with the area of $1 \mathrm{~cm}^{2}$ and to $23.7 \%$ for the area of $0.074 \mathrm{~cm}^{2}$ $[2,4]$. The most common methods to fabricate organic/inorganic lead halide perovskite are the so-called one-step solution deposition processes, in which all components are first solved in an organic solvent, such as N-dimethylformamide (DMF), then deposited on a substrate, and finally are thermally treated $[5,6]$. The production of perovskite thin films is possible with the use of many different deposition methods, such as spin-coating [7], deposition by dipping into a solution [8], blade-coating [9], sputtering [10], and vacuum deposition [11]. The use of other solvents has been reported, such as butyrolactone [12] or dimethyl sulfoxide [13]. All the factors (deposition methods and solvents used) have a strong effect on the crystallization processes. Therefore, the films obtained are characterized by different morphologies (the shape and the size of grains) and, correspondingly, by different crystal structure defects both on the grain boundaries and in the films. In polycrystalline films, grain size, their defect types, and orientation strongly affect their optical and photoelectric properties. For the photoconversion, optical and photoelectric characteristics are the most crucial. As a rule, they are studied in the already fabricated SCs, which consist of several layers in addition to the perovskite layer. As a result, the characteristics measured are integrated, that is, it is often difficult to single out the contributions of individual layers, which is important, when production technologies are being developed. In [14], the roles of the selective contacts to methylammonium lead iodide chloride $\left(\mathrm{MAPbI}_{3-x} \mathrm{Cl}_{x}\right)$ have studied using surface photovoltage (SPV) spectroscopy. By depositing and characterizing each layer at a time, it was shown that the electron-extracting interface is more than twice as effective as the holeextracting interface in generating a photovoltage for several combinations of electrode materials. Their results illustrate the usefulness of SPV spectroscopy for the study and characterization in perovskite-based photovoltaics. In that work, the surface photovoltage $V_{S P V}$ was measured in a non-contact manner in a large signal mode (photovoltage values varied with- ing tens-hundreds $\mathrm{mV}$ ), when the surface photovoltage value $V_{\mathrm{SPV}}$ is much greater, than the thermal voltage $V_{\mathrm{SPV}} \gg k T / q$. Here, $k$ is Boltzmann's constant, $T$ is the temperature, and $q$ is the elementary charge. At $T=300 \mathrm{~K}, k T / q=25.9 \mathrm{mV}$. For the first time, the method of spectral dependences of smallsignal surface photovoltage $\left(V_{\mathrm{SPV}} \ll k T / q\right)$ to determine of the diffusion length of the minority charge carriers by Goodman in $\mathrm{CH}_{3} \mathrm{NH}_{3} \mathrm{PbI}_{3}$ thin films and powders was used by Dittrich et al. [15]. Goodman's approach is valid for a semiinfinite plane-parallel sample with an optically mirror surface and is based on the formula:

$\Delta n=\frac{(1-R) I}{S+D / L} \frac{\alpha L}{1+\alpha L}$,

where $\Delta n$ is the concentration of minority charge carriers, $R$ is the reflectance coefficient from the front surface, $I$ is the photon flux per unit surface, $\alpha=\alpha(\lambda)$ is the absorption coefficient of the film, and $L$ is the diffusion length of minority charge carriers. Expression (1) used to calculate the minority carrier diffusion length was obtained at the approximations $d \gg L ; W \ll L ; \alpha W \ll 1 ; \alpha(d-W) \gg 1$; $\Delta n \ll p_{0}$. Here, $d$ is the film thickness, and $W$ is the surface space-charge region width. Since the experimentally measured quantity is $V_{\mathrm{SPV}}$, for obtaining proportionality $V_{\mathrm{SPV}} \sim \Delta n$, it is necessary that the criterion of small signal $V_{\mathrm{SPV}} \ll k T / q$ have to be done. In their study [15], the magnitude of the surface photovoltage signal did not exceed $120 \mu \mathrm{V}$, which indeed corresponds to the criterion $V_{\mathrm{SPV}} \ll k T / q$. However, the second important criterion, $L \ll d$, was not met in their study. The authors obtained their results in the case of $L \approx d$, which leads to a significant error to determine $L$. This is the main factor. The surface of the perovskite films is not specular, but has a certain relief, thus, the light rays direction in the film is not a perpendicular to the surface. Therefore, the Goodman approach has used by Dittrich [15] cannot, in principle, to give the exact diffusion length for minority charge carriers in perovskite films with a relief surface. Weng [16] also applied the Goodman surface photovoltage spectroscopy method to determine the diffusion length of minority charge carriers in $\mathrm{CH}_{3} \mathrm{NH}_{3} \mathrm{PbBr}_{3}$ crystals. In their measurements, all the criteria of the method were met, except the small signal: the surface photovoltage values were $V_{\mathrm{SPV}}=70-200 \mathrm{mV}$, which is $3-4$ times higher

ISSN 2071-0194. Ukr. J. Phys. 2021. Vol. 66, No. 5 
than $k T / q$, but not vice versa. Thus, there are no grounds for claiming the accurate measurement of the diffusion length. We can only talk about rough estimates of its value obtained in those works [16]. In the present work, it is proposed to use the method of spectrally resolved small-signal surface photovoltage together with the measurements of the optical properties (transmission and reflection) for the characterization and development of fabrication technologies of perovskite films with different microstructures. It will be shown that the spectral dependence of the smallsignal surface photovoltage $V_{\mathrm{SPV}}(\lambda)$ is proportional to the external $\operatorname{EQE}(\lambda)$ and internal quantum efficiencies IQE $(\lambda)$ of photogeneration (imply photocurrent) $[17,18]$. The methods proposed allow one to establish the mechanism of surface photovoltage formation, to obtain the bandgap value in a perovskite film, as well as the diffusion length for non-equilibrium minority charge carriers or photon path length values (if the absorption coefficient is known), and to estimate the surface recombination rate from the shortwavelength part of the photovoltage spectrum.

\section{Experimental Methods}

\subsection{Synthesis method}

Lead iodide $\mathrm{PbI}_{2}$, methylammonium chloride $\mathrm{CH}_{3} \mathrm{NH}_{3} \mathrm{Cl}$ (C.P.), and methylammonium iodide $\mathrm{CH}_{3} \mathrm{NH}_{3} \mathrm{I}$ that was pre-synthesized were used as the input reagents [19]. In order to stabilize the perovskite structure, the partial replacement of iodine with chlorine was carried out [20] using methylammonium chloride $\mathrm{CH}_{3} \mathrm{NH}_{3} \mathrm{Cl}$ (C.P.). Dried dimethylformamide (DMF, C.P.) was used as a solvent. To obtain the $\mathrm{CH}_{3} \mathrm{NH}_{3} \mathrm{PbI}_{2.98} \mathrm{Cl}_{0.02}$ films, the input reagents $\mathrm{PbI}_{2}, \mathrm{CH}_{3} \mathrm{NH}_{3} \mathrm{I}$, and $\mathrm{CH}_{3} \mathrm{NH}_{3} \mathrm{Cl}$ were dissolved in $\mathrm{DMF}$ in stoichiometric proportions and mixed for $1 \mathrm{~h}$ at $70{ }^{\circ} \mathrm{C}$. The synthesis was performed in a dry box. The so obtained transparent solution was then deposited onto a pre-cleaned substrate by the spin-coating at 1200 rotations per minute during 30 seconds. Glass or ITO-coated glass (denoted hereafter as ITO/glass) was used as a substrate. The thermal treatment of the films was carried out on a pre-heated stove at $90{ }^{\circ} \mathrm{C}$ for $30 \mathrm{~min}$. The products were characterized by X-ray powder diffraction taken on a DRON-4-07 (CuK $\alpha$-radiation, $40 \mathrm{kV}$, $18 \mathrm{~mA}$ ) in the $2 \Theta=10-70^{\circ}$ interval with the step size of $0.02^{\circ}$ and exposition time of $6 s$. The unit cell parameters were determined using the Rietveld full-profile analysis method of the data.

\subsection{Measurements of the physical characteristics}

The spectral characteristics of the surface photovoltage were measured in the wavelength interval $\Delta \lambda=400$ $900 \mathrm{~nm}$ on the perovskite $\mathrm{CH}_{3} \mathrm{NH}_{3} \mathrm{PbI}_{2.98} \mathrm{Cl}_{0.02}$ films deposited on glass with an ITO layer. The measurements were performed at a constant flux of photons of monochromatic light. The spectra obtained from these measurements are proportional to the external and internal quantum efficiencies. The diagram of the experimental set-up for surface photovoltage measurements is shown in Fig. 1. The light of a halogen lamp passed a monochromator and a beam splitter and was directed onto the experimental sample. Surface photovoltage measurements were performed with a non-destructive method using a press-on ITO electrode with the area $\sim 7 \times 7 \mathrm{~mm}^{2}$ deposited on mica $\sim 5 \mu \mathrm{m}$ in thickness. The spectral measurements were carried according to ASTM standards [21] on a set-up for the determination of spectral characteristics of photoconverters in the Center for testing of photoconverters and photoelectric batteries at the V.E. Lashkaryov Institute of Semiconductor Physics of the NAS of Ukraine. The transmission spectra in the wavelength interval $\Delta \lambda=400-900 \mathrm{~nm}$ were measured on the perovskite $\mathrm{CH}_{3} \mathrm{NH}_{3} \mathrm{PbI}_{2.98} \mathrm{Cl}_{0.02}$ film samples deposited on glass without an ITO layer. A silicon etalon photodiode was used as a reference photosensor (etalon in Fig. 1). An AC voltage with a frequency of $20 \mathrm{~Hz}$ driving an oscillating beam splitter was used as a reference signal for the lock-in amplifier. The reflection coefficient was estimated for a wavelength of $632.8 \mathrm{~nm}$. The measurements have revealed that the reflection had diffusive character, and the reflection coefficient was quite small, estimated to be $\sim 5 \%$.

\section{Results and Discussion}

To determine the unit cell parameters of the $\mathrm{CH}_{3} \mathrm{NH}_{3} \mathrm{PbI}_{2.98} \mathrm{Cl}_{0.02}$ material synthesized with the use of the full-profile Rietveld method, the x-ray diffraction patterns of the single-phase samples were used, one of which is shown in Fig. 2. Calculations of the structure parameters indicate that this diffractogram corresponds to the tetragonal symmetry 


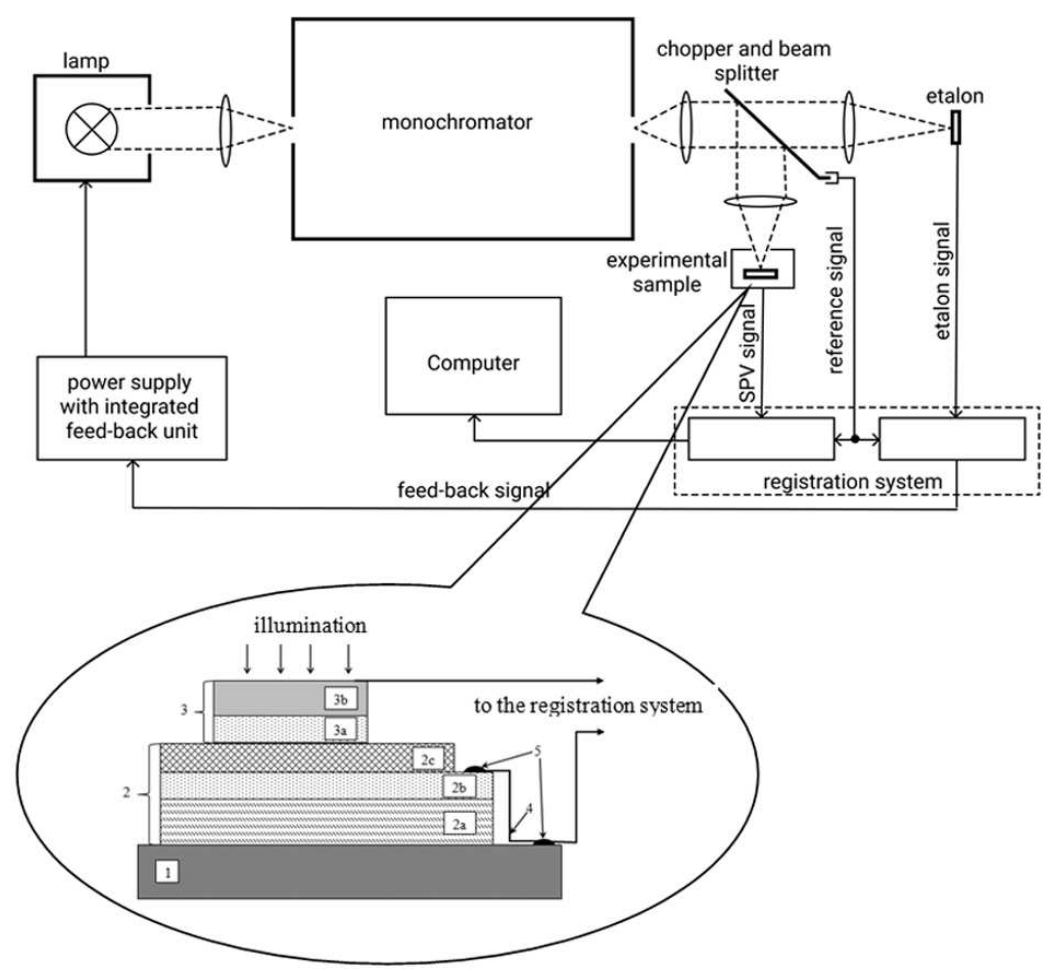

Fig. 1. Diagram of the experimental set-up for surface photovoltage (SPV) measurement

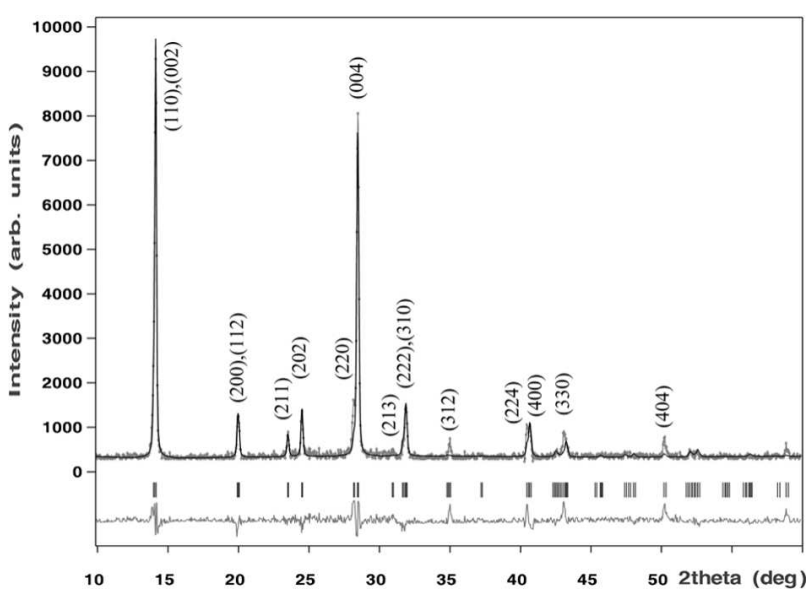

Fig. 2. Experimental (symbols) and theoretical (curves) Xray diffractograms of a $\mathrm{CH}_{3} \mathrm{NH}_{3} \mathrm{PbI}_{2.98} \mathrm{Cl}_{0.02}$ film sample after the thermal processing at $90{ }^{\circ} \mathrm{C}$. The vertical lines indicate peak locations, with Miller indices given in the brackets. The difference curve is shown below

(I4/mcm space group, No. 140), which agrees with the literature data [22].

For the calculations, the atomic coordinates from this work were used for $\mathrm{Pb}(4 c) 000 ; \mathrm{I} 1(8 h)$ xy0;
I2(4a) 00 $\frac{1}{4} ; \quad \mathrm{C}$ (16l) xyz; N (16l) xyz. For the $\mathrm{CH}_{3} \mathrm{NH}_{3} \mathrm{PbI}_{2.98} \mathrm{Cl}_{0.02}$ film the following lattice parameters were obtained: $a=8.870(2) \AA, c=$ $=12.669(8) \AA, V=996.8(7) \AA^{3}$. The microstructure analysis of the films obtained, see Fig. 3, shows that the ITO/glass substrate is incompletely covered by $\mathrm{CH}_{3} \mathrm{NH}_{3} \mathrm{PbI}_{2.98} \mathrm{Cl}_{0.02}$. The film morphology can be described as a net composed of non-oriented needlelike structures with a broad range of length to width ratios and the significant roughness and porosity of the film.

In general, the spectral dependence of the smallsignal surface photovoltage $V_{\mathrm{SPV}}(\lambda)$ can be described as [23]

$V_{\mathrm{SPV}}(\lambda)=A_{1}\left(\phi_{s}, \lambda\right) \operatorname{EQE}(\lambda)=A_{2}\left(\phi_{s}, \lambda\right) \operatorname{IQE}(\lambda),(2$

where $\phi_{s}$ is the band bending on the illuminated side of the film, $\lambda$ is the light wavelength, $A_{1}\left(\phi_{s}, \lambda\right)$ and $A_{2}\left(\phi_{s}, \lambda\right)$ are the coefficients with the dimensions of Volts, $\alpha(\lambda)$ is the light absorption coefficient, and $\operatorname{EQE}(\lambda)$ and $\operatorname{IQE}(\lambda)$ are the external and internal photocurrent generation quantum efficiencies. The relation between the external and internal quantum ISSN 2071-0194. Ukr. J. Phys. 2021. Vol. 66, No. 5 
efficiencies for a non-absorbing film has the form [24]

$\operatorname{EQE}(\lambda)=(1-R(\lambda)) \operatorname{IQE}(\lambda)$,

where $R(\lambda)$ is the reflection coefficient. Thus,

$A_{1}\left(\phi_{s}, \lambda\right)=(1-R(\lambda)) A_{2}\left(\phi_{s}, \lambda\right)$.

According to [25], the dependence of the absorbance $A_{n t}$ on $\lambda$ near the absorption edge for a parallel-plane specular structure with a single full reflection from the backside has the form

$A_{n t}=1-\exp (-2 \alpha(\lambda) d)$.

For the absorbance $A_{t}(\lambda)$ of a semiconductor substrate with nonspecular textured surfaces for the spectral region near the absorption edge $(\alpha d \ll 1)$, the following formula was obtained:

$A_{t}(\lambda)=\frac{\alpha(\lambda)}{\alpha(\lambda)+\frac{1}{4 d n_{r}^{2}}}=\left(1+\frac{1}{4 \alpha(\lambda) d n_{r}^{2}}\right)^{-1}$.

It was also assumed that the coefficient of reflection from the frontal surface is equal to 0 and from the back is equal to 1 . Formula (6) describes the absorption edge up to values $A_{t}(\lambda)=0.9$ exactly. When $A_{t}(\lambda)$ is greater than 0.9 , the error does not exceed $2 \%$ and rapidly decreases, when $A(\lambda)$ approaches 1 $[26,27]$. Assuming that each absorbed photon generates one electron-hole pair, and there is no recombination (the minority carrier diffusion length $L$ is much longer than the film thickness $d$ ), we can conclude that the formula for the internal quantum efficiency should have a similar form as (5) and (6), namely:

$\operatorname{IQE}_{n t}(\lambda)=1-\exp (-2 \alpha(\lambda) d)$

for a parallel-plane structure with specular surfaces and

$\operatorname{IQE}_{t}(\lambda)=\left(1+\frac{1}{4 \alpha(\lambda) d n_{r}^{2}}\right)^{-1}$

for a structure with nonspecular textured surfaces. Here, $d$ is the perovskite film thickness, and $n_{r}$ is its refraction index. Note that, for a plane-parallel structure with specular surfaces for $L \leq d / 3$, the internal quantum efficiency is well described by the well-known formula [28]

$\operatorname{IQE}(\lambda)=\frac{\alpha(\lambda) L}{1+\alpha(\lambda) L}=\left(1+\frac{1}{\alpha(\lambda) L}\right)^{-1}$,

where $L$ is the minority carrier diffusion length, and its value in this case can be found from the cut-off

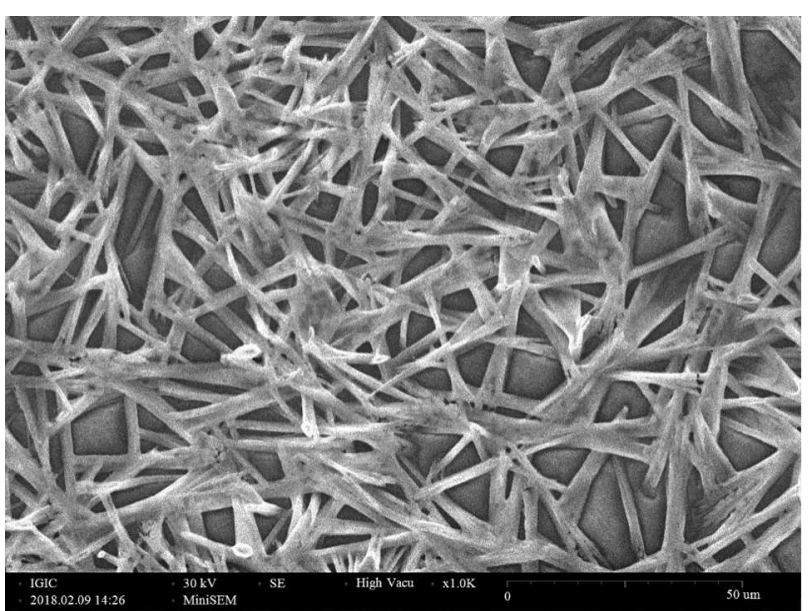

Fig. 3. $\mathrm{CH}_{3} \mathrm{NH}_{3} \mathrm{PbI}_{2.98} \mathrm{Cl}_{0.02}$ film microstructure after its thermal processing at $90{ }^{\circ} \mathrm{C}$

on the abscissa axis of the dependence of $\operatorname{IQE}(\lambda)^{-1}$ on $\alpha(\lambda)^{-1}$, if $\alpha(\lambda)$ is known [21]. In the case of a textured or profiled surface, this method will give significantly overestimated values of the diffusion length. As shown in $[25,29]$, the probability of the photon absorption in a long-wavelength region increases due to the Lambert scattering on a textured surfaces and an increase of its path length from the value of $2 d$ in a plane-parallel structure with a specular surface to the value of $4 d n_{r}^{2}$ in a textured structure. This is the difference between expressions (7) and (8). The texturing is known to be responsible for the higher values of the quantum efficiency, the short-circuit current, and, hence, the photoconversion efficiency. An increase of the photoconversion efficiency is not only due to an increased photon path length, which leads to a broadening of the quantum efficiency with $\lambda$ and to its shifting toward the longer wavelengths; it is also due to a reduced frontal reflection coefficient value. This is related to the nonperpendicular light incidence on the textured elements of the structure, which leads to an increase in the photon path length due to the multiple total internal reflection and to an increase in the absorption in the long-wavelength region. It was established in $[30,31]$ that the absorption edge in silicon HIT SCs and $\mathrm{FAPbI}_{3}$-based SCs can be described by the generalized expression which differs from (8) by the presence of the parameter $b$ :

$\operatorname{IQE}_{t}^{*}(\lambda)=\left(1+\frac{b}{4 \alpha(\lambda) d n_{r}^{2}}\right)^{-1}$, 


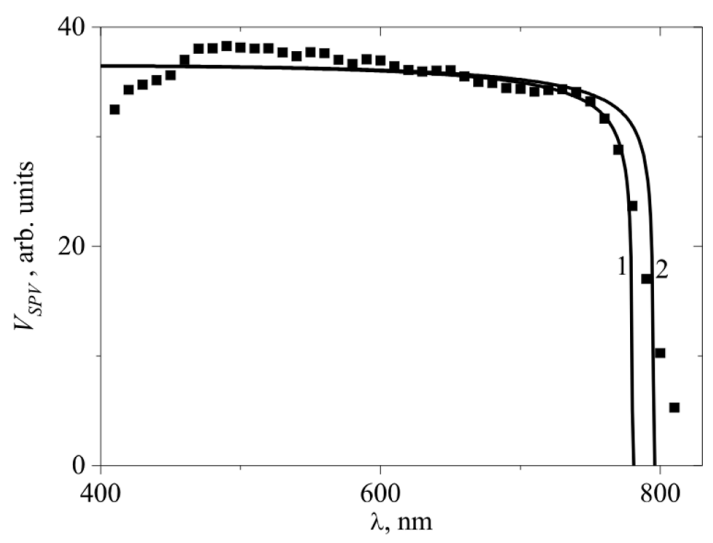

Fig. 4. Experimental (squares) and theoretical spectral dependences (lines) of the surface photovoltage $V_{\mathrm{SPV}}(\lambda)$ calculated using expressions (2), (10), and (11) for bandgap values equal to 1.59 (curve 1) and $1.56 \mathrm{eV}$ (curve 2)

where $b \geq 1$ is a dimensionless parameter equal to the ratio of the longest possible photon path length, $4 d n_{r}^{2}$ at the ideal Lambertian light trapping to its real value. This ratio depends on the texturing quality (degree of light capture) and the film thickness. We note that the case where expression (8) with $b=1$ is realized experimentally is rare. In particular, it was demonstrated in [30] that the experimental results for the textured silicon-based SCs and textured HIT SCs near the absorption edge can be described theoretically with a transformed expression of the form (10) with $b>1$. Comparing (9) and (10), it is easy to see that the dependence of the inverse quantum efficiency on the inverse absorption coefficient is similar in both cases. The difference lies in the cut-off value on the $a$ axis, which is equal to the diffusion length of minority carriers $-L$ for a flat surface and to the average path length of photons $l_{\mathrm{ph}}=4 d n_{r}^{2} / b$ for a textured one. Thus, in the case of a textured surface and diffusion lengths exceeding the thickness of the sample, we can determine the average path length of photons in the long-wavelength region of the spectrum near the absorption edge and the value of parameter $b$. Because organic-inorganic perovskites are direct-bandgap semiconductors, the absorption coefficient $\alpha(\lambda)$ near the absorption edge is given by the formula [32]

$\alpha(\lambda)=B \frac{\left(\frac{1239.7}{\lambda}-E_{g}\right)^{1 / 2}}{\frac{1239.7}{\lambda}}$,

where $B$ is a constant, $E_{g}$ is the bandgap value, and $\lambda$ is the wavelength in nm. Figure 4 shows the ex- perimental dependence $V_{\mathrm{SPV}}(\lambda)$ and the same dependences calculated using expressions (2), (10), and (11) for the bandgap values equal to 1.59 (curve 1) and $1.56 \mathrm{eV}$ (curve 2). We see a good agreement of the experimental curve with curve 1 . From this figure, one can conclude that the bandgap in the film investigated is equal to $1.59 \mathrm{eV}$.

The experimental dependence of the absorption coefficient is very important for the analysis and interpretation of the experimental spectra of the small-signal surface photovoltage. In this work, we used the most accurate dependence obtained in [33] over a wide range of wavelengths for perovskite $\mathrm{CH}_{3} \mathrm{NH}_{3} \mathrm{PbI}_{3}$. It is well known that the absorption edge in the structurally imperfect films is described by the Urbach rule. The empirical absorption coefficient depends on the photon energy in this wavelength range as

$\alpha_{u r}=\alpha_{u r 0} \exp \left(E_{\mathrm{ph}} / E_{0}\right)$,

where $\alpha_{u r 0}$ is the initial absorption coefficient, $E_{\mathrm{ph}}$ is photon energy, and $E_{0}$ is the characteristic energy, which is of the order of a few tens of $\mathrm{meV}$ for not too big deviations from that of the perfect films [34]. Figure 5 shows the experimental dependence of the small-signal surface photovoltage $\log \left(V_{\mathrm{SPV}}\right)$ on the energy $E=1239.7 / \lambda \mathrm{eV}$ normalized to the value at $\lambda=490 \mathrm{~nm}$ and the theoretical dependence of the quantum yield calculated using formula (12). As can be seen from the figure, their agreement takes place in the region $\lambda>790 \mathrm{~nm}$, if we put $E_{0}$ equal to $30 \mathrm{meV}$. The direction of the dependence of $V_{\mathrm{SPV}}(E)$ in semilogarithmic coordinates for $\lambda>790 \mathrm{~nm}$ indicates the presence of the Urbach effect. Thus, in the analysis, we will use the $\alpha(\lambda)$ [33] dependence corrected for the Urbach effect (12) for $\lambda>790 \mathrm{~nm}$.

Using formulas (2)-(10) and the corrected dependence $\alpha(\lambda)$ allows us to build the low-signal surface photovoltage spectral curves and to determine the key parameters (namely, the perovskite film thickness $d$ and the parameter $b$ ), at which they agree with the experiment near the absorption edge. More convenient for analysis are the spectral dependences of the small-signal surface photovoltage, which are constructed in the coordinates $V_{\mathrm{SPV}}^{-1}$ versus $\alpha^{-1}(\lambda)$ $[17,18]$. In these coordinates, dependences (9) and (10) are straightened up in the long-wavelength region, and the cut-off on the abscissa axis $-\alpha_{\text {cut-off }}^{-1}(\lambda)$ 


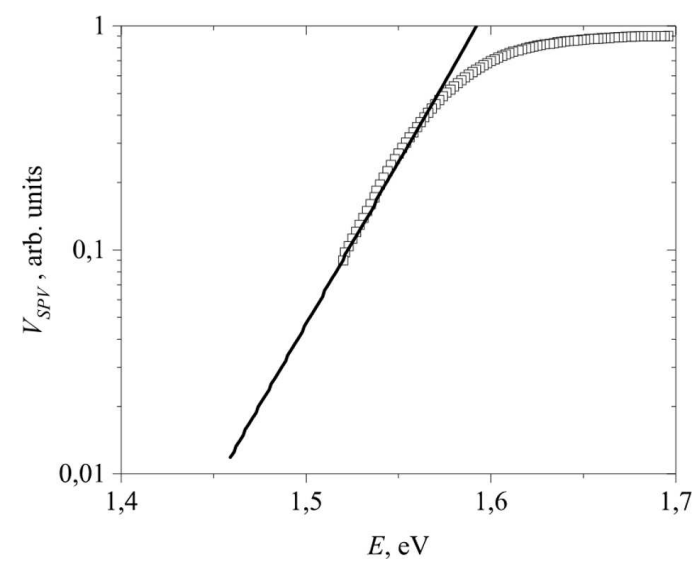

Fig. 5. Experimental spectral dependence of the surface photovoltage $V_{\mathrm{SPV}}(E)$ of the synthesized $\mathrm{CH}_{3} \mathrm{NH}_{3} \mathrm{PbI}_{2.98} \mathrm{Cl}_{0.02}$ films (squares). Line - theory (equation (12)). Urbach's energy is equal to $30 \mathrm{meV}$

is equal to the diffusion length $L$, when $-\alpha_{\text {cut-off }}^{-1}(\lambda) \leq$ $\leq d / 3$ according to $(9)$ and $-\alpha_{\text {cut-off }}^{-1}(\lambda)=4 d n_{r}^{2} / b$ according to (10) otherwise. Figure 6 shows the experimental and calculated dependences of the inverse small-signal surface photovoltage $V_{\mathrm{SPV}}^{-1}$ on the inverse values of the absorption coefficient $\alpha^{-1}(\lambda)$, for the $\mathrm{CH}_{3} \mathrm{NH}_{3} \mathrm{PbI}_{2.98} \mathrm{Cl}_{0.02}$ film. The dependences are constructed, by using expression (10) and the generalized value of $\alpha(\lambda)$ [32]. As can be seen from Fig. 6, the experimental values at the absorption edge agree with the theoretical line well, if we put $d=400 \mathrm{~nm}$, average path length $l_{\mathrm{ph}}=4650 \mathrm{~nm}$, and $b=4.3$. In this case, the cut-off on the abscissa axis $-\alpha_{\text {cut-off }}^{-1}(\lambda)=$ $=2.1 \mu \mathrm{m}$, which significantly exceeds the thickness of the perovskite film $d=0.4 \mu \mathrm{m}$. If one uses expression (7), the theory cannot fit the experiment for the film studied. Figure 7 shows the same dependences, but in the coordinates: surface photovoltage $V_{\mathrm{SPV}}$ versus wavelength $\lambda$. We see a good agreement of the theoretical result [curve 1, expression (10)] and experimental (squares) dependence. At the same time, when using expression (7) (plane-parallel structure, curve 2), there is no agreement between experiment and theory for the studied perovskite film in the absorption edge region.

Thus, it follows from this analysis that the film studied here captures light efficiently due to its natural profiling (texturing). This conclusion agrees with the microstructure data, see Fig. 3. The diffusion length of minority charge carriers $L$ in the $\mathrm{CH}_{3} \mathrm{NH}_{3} \mathrm{PbI}_{2.98} \mathrm{Cl}_{0.02}$ films synthesized by us exceeds

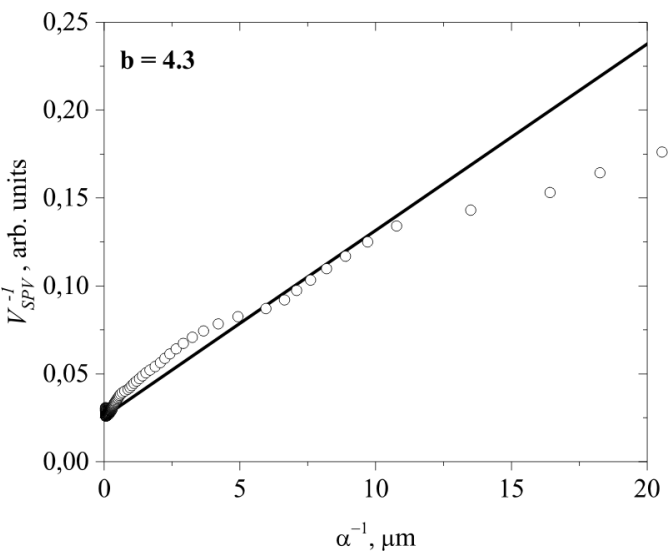

Fig. 6. Experimental (points) and calculated (line) dependences $V_{\mathrm{SPV}}^{-1}(\lambda)$ versus $\alpha^{-1} \lambda$, constructed using expression (10) and generalized values $\alpha(\lambda)$. Fitting parameters: $-\alpha_{\text {cut-off }}^{-1}(\lambda)=2.1 \mu \mathrm{m}, d=400 \mathrm{~nm}$, and $b=4.3$

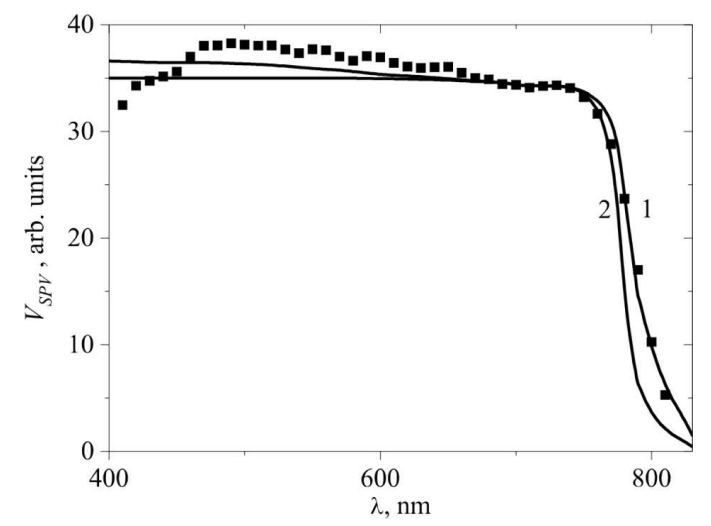

Fig. 7. Spectral dependences $V_{\mathrm{SPV}}(\lambda)$. Squares are experimental data, line (1) is a theoretical curve calculated using formulas (2) and (10), and line (2) is a theoretical curve calculated using formulas (2) and (7). Parameters used: $d=400 \mathrm{~nm}$, $b=4.3$

the sample thickness $d$, because of the spectra are described by expression (10). We note that the spectral curves of the small-signal surface photovoltage for the film illumination from the opposite sides are close to each other. This provides an additional evidence of the high diffusion length (exceeding the film thickness), which, according to [35], are of the order of $1 \mu \mathrm{m}$ in the samples with chlorine added. Let us now analyze the transmission spectra. Shown in Fig. 8 are the transmission spectra for a perovskite film on glass without ITO. The respective theoretical formulas are

$T_{n t}=\frac{(1-R)^{2} \exp (-\alpha d)}{1-R^{2} \exp (-2 \alpha d)}$ 


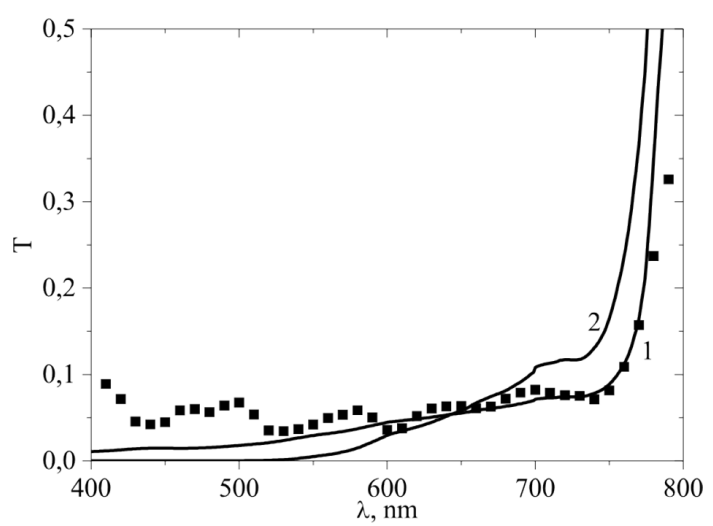

Fig. 8. Transmission spectra for a film without an ITO layer. Squares are experimental data. 1 - theoretical curve calculated using formula (14), 2 - theoretical curve calculated using formula (13). Parameters used: $d=400 \mathrm{~nm}, b=4.3$

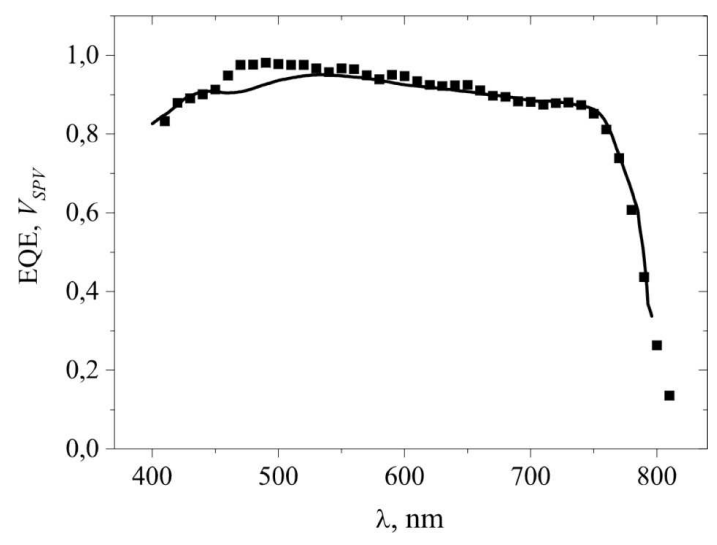

Fig. 9. Experimental (squares) and theoretical dependences (line) of the small-signal photovoltage $V_{\mathrm{SPV}}(\lambda)$ for the synthesized $\mathrm{CH}_{3} \mathrm{NH}_{3} \mathrm{PbI}_{2.98} \mathrm{Cl}_{0.02}$ films. Parameters are as follows: $D_{1}=2.5 \times 10^{-2} \mathrm{~cm}^{2} / \mathrm{s}, L_{1}=2.4 \times 10^{-6} \mathrm{~cm}, S_{0}=10^{6} \mathrm{~cm} / \mathrm{s}$, $d_{1}=100 \mathrm{~nm}, d=400 \mathrm{~nm}, b=4.3$

and

$T_{t}=(1-R)\left(1+\alpha(\lambda) l_{\mathrm{ph}}(d, b)\right)^{-1}$.

Expression (13) should be used for a plane-parallel structure, and relation (14) is valid for a textured structure (with the coefficient $b$ taken into account).

Let us determine the transmission coefficient according to (14) for a film without an ITO layer, and let us use the generalized value for $\alpha(\lambda)$ for perovskite $\mathrm{CH}_{3} \mathrm{NH}_{3} \mathrm{PbI}_{2.98} \mathrm{Cl}_{0.02}$ and the values $d=400 \mathrm{~nm}$ and $b=4.3$ (curve 1 ). In this case, the agreement between experiment and theory is quite good in the wavelength interval from $500 \mathrm{~nm}$ to $800 \mathrm{~nm}$. However, the determination of the transmission coefficient according to (13) gives no agreement between the theoretical curve 2 and the experiment in the whole spectral range. Thus, the experimental transmission spectra of the film without an ITO layer also confirm that the film is naturally textured. Let us now consider the causes for a $\operatorname{EQE}(\lambda)$ to decrease in the shortwavelength range in the perovskite SCs and the spectral dependence of the small-signal surface photovoltage $V_{\mathrm{SPV}}(\lambda)$, see Fig. 9. As for the short-wavelength decrease of $V_{\mathrm{SPV}}(\lambda)$, it was shown $[23,36]$ that this decrease has to do with the formation of a layer near the perovskite $\mathrm{CH}_{3} \mathrm{NH}_{3} \mathrm{PbI}_{2.98} \mathrm{Cl}_{0.02}$ surface with the carrier lifetime shorter than in bulk. Shown in Fig. 9 are the experimental and theoretical dependences of $V_{\mathrm{SPV}}(\lambda)$ normalized to the highest value for a perovskite films synthesized in this work.

The calculation of the curve $V_{\mathrm{SPV}}(\lambda)$ for a $\mathrm{CH}_{3} \mathrm{NH}_{3} \mathrm{PbI}_{2.98} \mathrm{Cl}_{0.02}$ perovskite film, which gives a decrease at short wavelengths, was performed using the following formula for the effective surface recombination rate

$S_{\text {eff }}(\lambda)=\frac{D_{1}}{L_{1}} \frac{S_{0} \frac{L_{1}}{D_{1}} \cosh \left(\frac{1}{\alpha(\lambda) L_{1}}\right)+\sinh \left(\frac{1}{\alpha(\lambda) L_{1}}\right)}{S_{0} \frac{L_{1}}{D_{1}} \sinh \frac{1}{\alpha(\lambda) L_{1}}+\cosh \left(\frac{1}{\alpha(\lambda) L_{1}}\right)}$

taken from Ref. [36]. Here, $D_{1}$ and $L_{1}$ are, respectively, the diffusion coefficient and diffusion length in the surface layer of thickness $d_{1}$, and $S_{0}$ is the effective surface recombination velocity under the condition $\alpha d_{1} \gg 1$. The theoretical $V_{\mathrm{SPV}}(\lambda)$ curve was built using the following parameter values: $D_{1}=$ $=2.5 \times 10^{-2} \mathrm{~cm}^{2} / \mathrm{s}, L_{1}=2.4 \times 10^{-6} \mathrm{~cm}, S_{0}=$ $=10^{6} \mathrm{~cm} / \mathrm{s}, d_{1}=100 \mathrm{~nm}, d=400 \mathrm{~nm}, b=4.3$. As seen from Fig. 9, the agreement between the experimental $V_{\mathrm{SPV}}(\lambda)$ curve for the $\mathrm{CH}_{3} \mathrm{NH}_{3} \mathrm{PbI}_{2.98} \mathrm{Cl}_{0.02}$ film and the theoretical counterpart, it can be considered as satisfactory.

\section{Conclusions}

In the present work, the efficiency of the method of spectrally resolved small-signal surface photovoltage has been demonstrated together with the measurements of the optical properties (transmission and reflection) for the characterization of perovskite films. In particular, the methodology proposed allows one to consistently determine the bandgap value of a perovskite film, as well as its minority carriers diffusion length in the case $L \leq d / 3$ for a parallel-plane

ISSN 2071-0194. Ukr. J. Phys. 2021. Vol. 66, No. 5 
sample with specular surfaces or to estimate its value in the case of large diffusion lengths and/or textured surfaces. It has been shown that the small signal surface photovoltage spectral dependences $V_{\mathrm{SPV}}(\lambda)$ is proportional to the external $\operatorname{EQE}(\lambda)$ and internal quantum efficiencies $\operatorname{IQE}(\lambda)$ of photogeneration. It is shown that, in the case of a textured surface and diffusion lengths exceeding the thickness of the sample, the cut-off on the abscissa axis of the dependence of the inverse surface photovoltage on the inverse absorption coefficient is equal to the average path length of photons in the long-wavelength region of the spectrum near the absorption edge. A method is proposed for determining the average path length of photons and the value of parameter $b$. The detailed analysis of the surface photovoltage spectra indicates that, in the films mentioned above, the Urbach effect plays an essential role near the absorption edge. One can obtain good agreement of the theory with the experiment and to deduce an accurate value of the perovskite film bandgap to be $1.59 \mathrm{eV}$ only by taking this effect into account. It has been established by comparing the experimental spectral curves of the smallsignal surface photovoltage with the theory for textured structures that the films studied are naturally profiled. This agreement between the theory for textured structures and the experiment means that the diffusion length of the non-equilibrium charge carriers in the $\mathrm{CH}_{3} \mathrm{NH}_{3} \mathrm{PbI}_{2.98} \mathrm{Cl}_{0.02}$ perovskite films exceeds the film thickness. This is also supported by the results of a comparison between the spectra of the small-signal surface photovoltage obtained, when the film was illuminated from the opposite sides. The value of the surface recombination rate for the perovskite film was estimated to be about $10^{6} \mathrm{~cm} / \mathrm{s}$. It is established that the use of the transformed formula (10) allows one to make the theory consistent with the experiment not only near the absorption edge, but also to the EQE values up to $\sim 0.9$.

1. M.A. Green, A. Ho-Baillie, H.J. Snaith. The emergence of perovskite solar cells. Nature Photonics 8, 7 (2014).

2. M.A. Green, Y. Hishikawa, E.D. Dunlop et al. Solar cell efficiency tables (Version 53). Prog. Photovolt. Res. Appl. 27, (2019).

3. M.A. Green. Third Generation Photovoltaics. Advanced Solar Energy Conversion. (Springer, 2006).

4. W.S. Yang et al. High-performance photovoltaic perovskite layers fabricated through intramolecular exchange. Science 348, 6240 (2015).

ISSN 2071-0194. Ukr. J. Phys. 2021. Vol. 66, No. 5
5. D. Song et al. Managing carrier lifetime and doping property of lead halide perovskite by postannealing processes for highly efficient perovskite solar cells. J. Phys. Chem. C 119, 40 (2015).

6. M.M. Lee, J. Teuscher, T. Miyasaka, T.N. Murakami, H.J. Snaith. Efficient hybrid solar cells based on mesosuperstructured organometal halide perovskites. Science 338, 2 (2012).

7. B.-E. Cohen, S. Gamliel, L. Etgar. Parameters influencing the deposition of methylammonium lead halide iodide in hole conductor free perovskite-based solar cells. APL $M a$ terials 2, 8 (2014).

8. J.-H. Im, I.-H. Jang, N. Pellet, M. Gratzel, N.-G. Park. Growth of $\mathrm{CH}_{s} \mathrm{NH}_{s} \mathrm{Pbl}_{s}$ cuboids with controlled size for high-efficiency perovskite solar cells. Nature Nanotech. 9, 11 (2014)

9. J. Burschka et al. Sequential deposition as a route to highperformance perovskite-sensitized solar cells. Nature $\mathbf{4 9 9}$, 7458 (2013)

10. J.H. Kim, S.T. Williams, N. Cho, C.C. Chueh, A.K.Y. Jen. Enhanced environmental stability of planar heterojunction perovskite solar cells based on blade-coating. Adv. Energy Mater. 5, 4 (2014).

11. K. Hwang et al. Toward large scale roll-to-roll production of fully printed perovskite solar cells. Adv. Mater. 27, 7 (2015).

12. J. Borchert, H. Boht, W. Franzel, R. Csuk, R. Scheer, and P. Pistor. Structural investigation of co-evaporated methyl ammonium lead halide perovskite films during growth and thermal decomposition using different $\mathrm{PbX}_{2}(\mathrm{X}=\mathrm{I}, \mathrm{Cl})$ precursors. J. Mater. Chem. A 3, 39 (2015).

13. J.-H. Im, C.-R. Lee, J.-W. Lee, S.-W. Park, N.-G. Park. $6.5 \%$ efficient perovskite quantum-dot-sensitized solar cell. Nanoscale 3, 10 (2011).

14. L. Barnea-Nehoshtan, S. Kirmayer, E. Edri, G. Hodes, D. Cahen. Surface photovoltage spectroscopy study of organo-lead perovskite solar cells. J. Phys. Chem. Lett. 5, (2014).

15. Th. Dittrich, F. Lang, O. Shargaieva, J. Rappich, N.H. Nickel, E. Unger, B. Rech. Diffusion length of photo-generated charge carriers in layers and powders of $\mathrm{CH}_{3} \mathrm{NH}_{3} \mathrm{PbI}_{3}$ perovskite. Appl. Phys. Lett. 109, 073901 (2016).

16. J. Wang, E. Motaharifar, L.N.S. Murthy, et al. Revealing lattice and photocarrier dynamics of high-quality $\mathrm{MAPbBr}_{3}$ single crystals by far infrared reflection and surface photovoltage spectroscopy. J. Appl. Phys. 125, 025706 (2019).

17. L. Kronik, Y. Shapira. Surface photovoltage phenomena: theory, experiment, and applications. Surf. Sci. Rep. 37, 1 (1999).

18. D.K. Schroder. Surface voltage and surface photovoltage: history, theory and applications. Meas. Sci. Technol. 12, R16 (2001).

19. J. Qiu et al. All-solid-state hybrid solar cells based on a new organometal halide perovskite sensitizer and onedimensional $\mathrm{TiO}_{2}$ nanowire arrays. Nanoscale 5, 8 (2013). 
20. A.G. Belous, O.I. V'yunov, S.D. Kobylyanskaya, A.A. Ishchenko, A.V. Kulinich. Influence of synthesis conditions on the morphology and spectral-luminescent properties of films of organic-inorganic perovskite $\mathrm{CH}_{3} \mathrm{NH}_{3} \mathrm{PbI}_{2.98} \mathrm{Cl}_{0.02}$. Rus. J. General Chem. 88, 1 (2018).

21. ASTM Standard F391-90a, "Standard Test Method for Minority-Carrier Diffusion Length in Silicon by Measurement of Steady-State Surface Photovoltage", 1996 Annual Book of ASTM Standards (Am. Soc. Test. Mat., 1996).

22. Y. Kawamura, H. Mashiyama, K. Hasebe. Structural study on cubic-tetragonal transition of $\mathrm{CH}_{3} \mathrm{NH}_{3} \mathrm{PbI}_{3}$. J. Phys. Soc. of Japan 71, 7 (2002).

23. A.V. Sachenko et al. Recombination characteristics of single-crystalline silicon wafers with a damaged nearsurface layer. Ukr. J. Phys. 58, 2 (2013).

24. C. Honsberg, S. Bowden. (30.10.2018). Quantum Efficiency (PVEducation ed.) [Internet]. Available: https:// www.pveducation.org/pvcdrom/solar-cell-operation/ quantum-efficiency.

25. T. Tiedje, E. Yablonovitch, G.D. Cody, B.G. Brooks. Limiting efficiency of silicon solar cells. IEEE Transactions on Electron Devices 31, 5 (1984).

26. M.A. Green. Lambertian light trapping in textured solar cells and light-emitting diodes: Analytical solutions. Prog. Photovolt: Res. Appl. 10, (2002).

27. S. Schafer, R. Brendel. Accurate calculation of the absorptance enhances efficiency limit of crystalline silicon solar cells with Lambertian light trapping. IEEE J. Photovoltaics 8, 4 (2018).

28. A. Fahrenbruch, R. Bube. Fundamentals of Solar Cells: Photovoltaic Solar Energy Conversion (Elsevier, 2012) [ISBN: 978-0122476808].

29. E. Yablonovitch. Statistical ray optics. JOSA 72, 7 (1982).

30. A.V. Sachenko et al. Peculiarities of photoconversion efficiency modeling in perovskite solar cells. Tech. Phys. Lett. 43, 7 (2017).

31. A.V. Sachenko et al. The effect of base thickness on photoconversion efficiency in textured silicon-based solar cells. Tech. Phys. Lett. 44, 10 (2018).

32. K. Seeger. Semiconductor Physics (Springer Science \& Business Media, 2004).

33. Stefaan De Wolf, J. Holovsky, S.-J. Moon, P. Loper, B. Niesen, M. Ledinsky, F.-J. Haug, J.-H. Yum, C. Ballif. Organometallic halide perovskites: Sharp optical absorption edge and its relation to photovoltaic performance. J. Phys. Chem. Lett. 5, (2014).

34. J.D. Joannopoulos, G. Lucovsky. The Physics of Hydrogenated Amorphous Silicon II: Electronic and Vibrational Properties (Springer Science and Business Media, 1984).
35. C. Wehrenfennig, G.E. Eperon, M.B. Johnston, H.J. Snaith, L.M. Herz. High charge carrier mobilities and lifetimes in organolead trihalide perovskites. Adv. Mater. 26, 10 (2013).

36. V.P. Kostylyov, V.G. Lytovchenko, A.V. Sachenko, T.V. Slusar, V.V. Chernenko. Features of solar cells and solar silicon wafers surface photovoltage spectral dependences in the short-wave absorption region, in Proceedings 28 European Photovoltaic Solar Energy Conf. and Exhib. (Paris, France, 2013), p. 1715.

Received 26.03.20

В.П. Костилъов, А.В. Саченко, В.М. Власюк,

I.О. Соколовсъкий, С.Д. Кобилянсъка, П.В. Торчинюк,

О.І. В'юнов, А.Г. Білоус

\section{СИНТЕЗ І ДОСЛІДЖЕННЯ ВЛАСТИВОСТЕЙ}

ПЛІВОК ОРГАНО-НЕОРГАНІЧНИХ ПЕРОВСКІТІВ БЕЗКОНТАКТНИМИ МЕТОДАМИ

В роботі наведено результати дослідження фотоелектричних характеристик плівок перовскіту $\mathrm{CH}_{3} \mathrm{NH}_{3} \mathrm{PbI}_{2,98} \mathrm{Cl}_{0,02}$, нанесених на скляну підкладинку методом spin-coating. 3 використанням рентгенівських методів дослідження визначено параметри елементарної комірки перовскіту та показано, що морфологія плівок описується як сітка неорієнтованих голкоподібних структур із значною шорсткістю та пористістю. Для дослідження властивостей отриманих плівок використовувались безконтактні методи, зокрема, вимірювання пропускання і відбивання та метод спектральних залежностей малосигнальної поверхневої фотонапруги. Показано, що метод спектральних залежностей малосигнальної поверхневої фотонапруги та метод пропускання містять інформацію про зовнішній квантовий вихід в досліджуваних плівках та про довжину дифузії неосновних носіїв у плівках перовскіту. В результаті аналізу спектрів встановлено, що отримані плівки є природно профільованими, а їхня ширина забороненої зони становить 1,59 еВ. Показано, що при визначенні залежності коефіцієнта поглинання та ширини забороненої зони слід враховувати ефект Урбаха. Довжина дифузії неосновних носіїв заряду більша за товщину плівок, яка дорівнює 400 нм. Отримані плівки є перспективними для розробки на їх основі ефективних сонячних елементів.

Kлючов $i$ слова: поверхнева фотонапруга, плівка перовскіту, довжина дифузіі, передача спектрів, ефект Урбаха. 